\title{
全日冷房時と間けつ冷房時における熱負荷の実測值と 計算值の比較
}

正会員井上等市* 同 ○尾荀俊 雄**

冷房負荷の実測を行ならと，決。て冷凍機遭転開始時 の午前中にピークを示す。これは建物や家具や装置の蓄 熱に起因すると考えられる。しかし従来その実測例を見 ないが，昨年高砂熱学の好意によって70時間連続空調運 転を行ない全日冷房時の熱負荷を実測し得たので，その 結果を報告する。間けつ冷房時・全日冷房時とむに契測 值と計算值は定量的に $10 \%$ 程異なる。これを実測や計算 誤差と考えれば，大体定性的に悢く一致しているとい えよう。間けつ運転時（図一1）において，家具や建物 の蓄冷負荷の占める割合が室内熱取得の50\%近く占めて いる。また日射や照明の熱取得計算には Carrier の24
㸡間運転時 Storage ${ }^{\circ}$ Factor を用いたものである。また 室温変動による蓄熱負荷は（文献 2）参照。奏測冷凍機 負荷とはクーラ出口部の泠水回りからの実測值に井水の 予冷負荷を加えたものである。間けつ冷房時に颃いては 運転開始前に日射による室温の急上昇がある。図一1は これを考慮して計算している。なお奏測や計算に当って は当時早大学生の千葉・渡辺・小田島の各君の協力によ ることを記す。

\section{[参照文献]}

1) Carrier etc. Modern Air Conditioning H.V. 3rd. ed.

2）井上・尾島『趖物の暖冷房負の解析』機械学会講演要旨

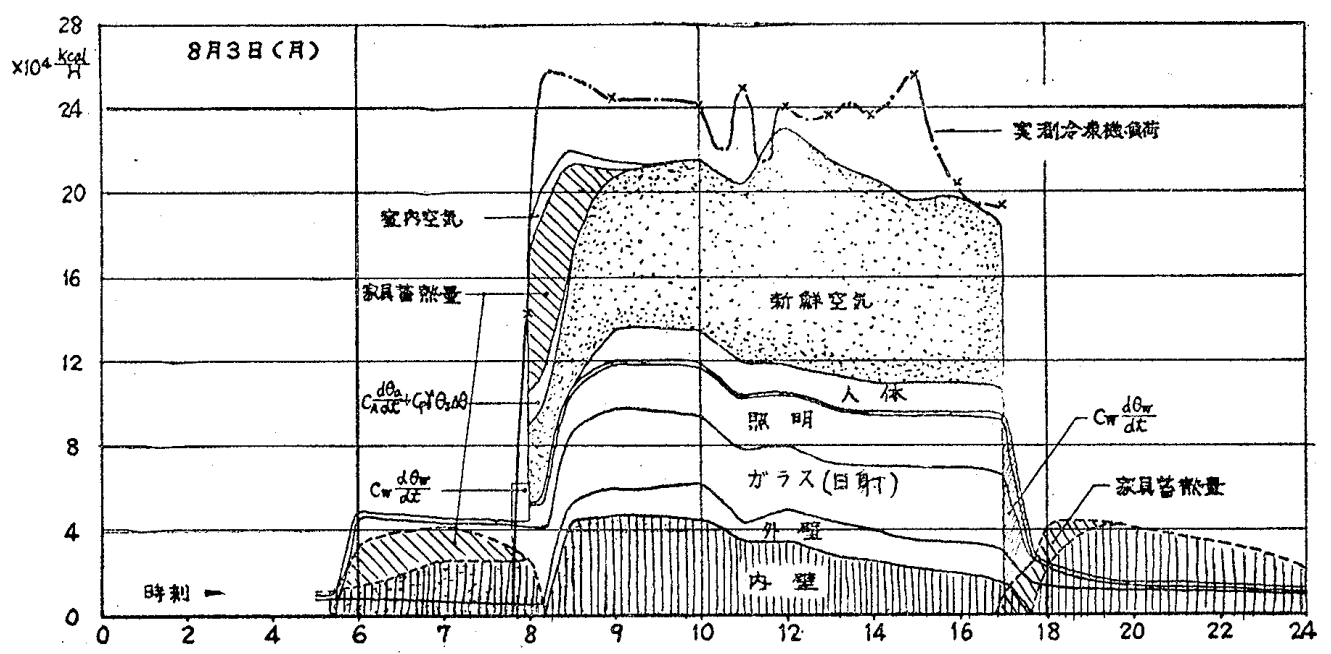

図一1 間けつ冷房時熱焦荷つ実測值と棓·算值の比較 (1964年 8 月 3 日月嚁, TA 熱学ピル)

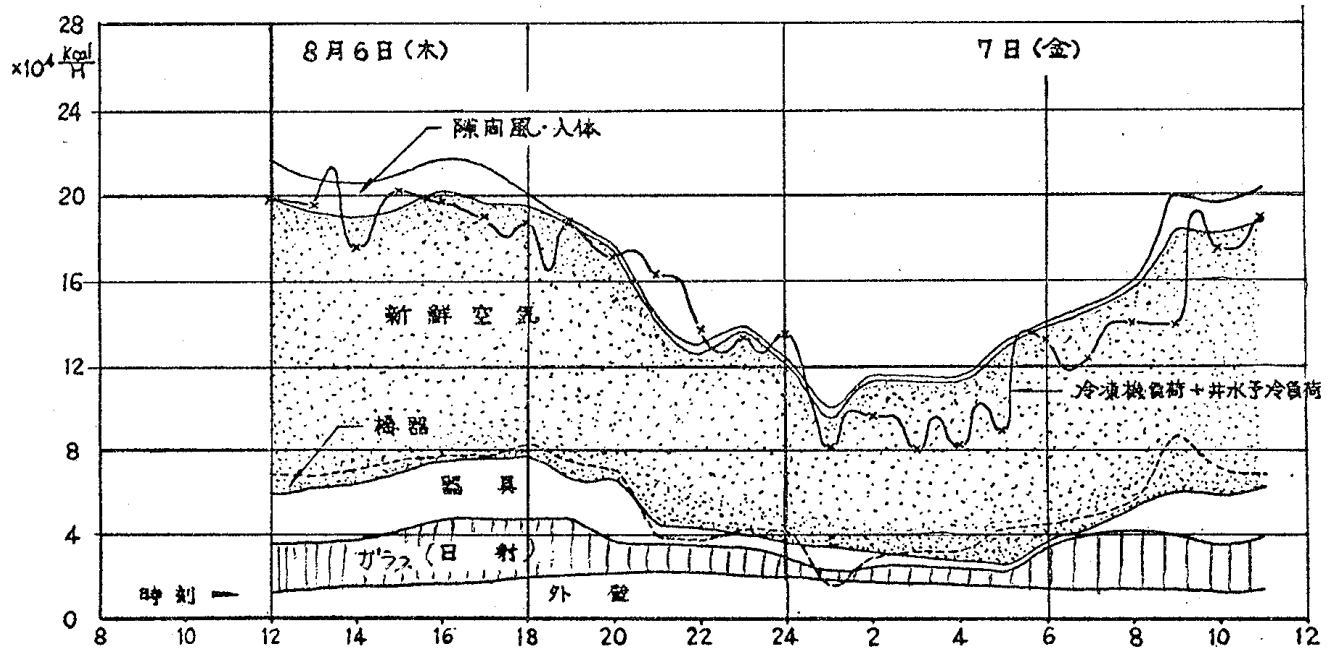

図一2 全日冷房時熱負荷の実測值と計算値の比較 (1964年8月 6 日木曜〜 7 日金曜, TA 熱学ビル)

\footnotetext{
* 早稲田大学教授・工博 $\quad * *$ 同講師
} 